\title{
Association between AgNORs and Immunohistochemical Expression of ER, PR, HER2/neu, and p53 in Breast Carcinoma
}

\author{
Hussain Gadelkarim Ahmed, ${ }^{1,2}$ Mohammed Ali Al-Adhraei, ${ }^{3}$ and Ibraheem M. Ashankyty ${ }^{4}$ \\ ${ }^{1}$ Department of Pathology, College of Medicine, Hail University, Hail, Saudi Arabia \\ ${ }^{2}$ Faculty of Medical Laboratory Sciences, University of Khartoum, Khartoum 11111, Sudan \\ ${ }^{3}$ National Oncology Center, Al-Jumhori Teaching Hospital, Sana'a, Yemen \\ ${ }^{4}$ Faculty of Applied Science, Hail University, Hail, Saudi Arabia \\ Correspondence should be addressed to Hussain Gadelkarim Ahmed, hussaingad1972@yahoo.com
}

Received 21 June 2011; Accepted 26 August 2011

Academic Editor: Qian Peng

Copyright ( 2011 Hussain Gadelkarim Ahmed et al. This is an open access article distributed under the Creative Commons Attribution License, which permits unrestricted use, distribution, and reproduction in any medium, provided the original work is properly cited.

Settings. Despite the limited diagnostic utility of AgNORs (argyrophilic nucleolar organiser region-associated proteins) for individual breast lesions, AgNOR analysis bears a significant potential for characterizing cell proliferative activity of breast lesions. Methodology. The present study investigated the relationship between mean AgNORs count and immunohistochemical expression of ER, PR, HER2/neu, and p53 in breast carcinoma in serial paraffin sections from 137 breast carcinomas. Twenty control cases of benign breast lesions were included. Results. Mean AgNOR counts correlated significantly inversely with hormone estrogen receptors (ER), Progesterone receptors (PR), and p53 immunohistochemical expression, denoting $P$ values of $0.05,0.01$, and 0.001, respectively. No significant correlation was found between mean AgNOR counts and HER2/neu, $P=0.9$. Mean AgNOR count was significantly higher in grade II tumor cells. We conclude that mean AgNOR counts correlate with ER, PR, and P53 tumor markers in breast carcinomas. Conclusion. We recommend the use of mean AgNOR count for accurate reporting of breast carcinomas, as well as prediction of ER, PR, and P53 in routine paraffin sections.

\section{Introduction}

Breast cancer is the top cancer in women both in the developed and the developing world [1]. Breast cancer survival rates vary greatly worldwide, ranging from $80 \%$ or over in North America, Sweden, and Japan to around $60 \%$ in middle-income countries and below $40 \%$ in lowincome countries [2]. The low survival rates in less developed countries can be explained mainly by the lack of early detection programmes, resulting in a high proportion of women presenting with late-stage disease, as well as by the lack of adequate diagnosis and overall management facilities [1].

Since breast cancer is one of the hormone-dependent tumors much attention has been paid to the relationship between ER and PR and breast cancer. The study by Blanco et al. [3] showed that ER+ PR+ patients had better prognosis than ER-PR- patients. In late 1970s and early 1980s, the measurement of ER as well as PR became standard practice in the prediction of the outcome of breast cancer patients [4].

Early observations after the identification of the p53 protein suggested that p53 functioned as an oncogene. In fact, it does, but only in the mutated form. In the late 1980s, however, several discoveries proved that the normal function of p53 was antioncogenic. One of the several functions of the normal p53 gene is suppression of cell proliferation. When DNA is damaged, p53 inhibits the progression of cell cycle from G1 to the S-phase or during S-phase $[5,6]$. The mutation of the p53 gene has been detected in almost $50 \%$ of human cancers including breast cancer $[7,8]$. Several studies demonstrated that mutations of p53 or increased nuclear expression of p53 protein is a prognostic factors in breast cancer and associated with worse prognosis $[9,10]$.

HER2/neu proto-oncogene encodes a $185-$ KDa transmembrane glycosylated epidermal growth factor receptor 
that contains an extracellular domain and has intracellular tyrosine kinase activity [11]. Amplification of the HER2/neu gene and overexpression of its protein are known to be characteristic of many breast cancers. Several studies have correlated the overexpression of the HER2/neu oncogene with poor prognosis in breast cancer patients [12, 13],

Nucleolar organiser regions (NORs) are loops of DNA that are responsible for ribosomal RNA (rRNA) transcription. They are located in the nucleoli of cells and in the chromosomes 13-15 and 21, 22 in association with proteins [14]. As rRNA molecules are the main sites of protein synthesis, it follows that the number of NORs in each cell nucleus reflects cellular activity [15]. The number and size of AgNORs can be assessed following staining of tissues or cells with silver stains [16].

AgNORs is correlate with the proliferative activity of neoplasms. Increased AgNOR counts may reflect increased proliferative activity of cells $[17,18]$. AgNOR counts have been studied in breast carcinoma, but the results have been conflicting. Some studies have demonstrated that quantitative analysis of AgNORs yields a prognostic factor in breast cancer [19].

AgNOR increasingly applied in histopathology research following suggestions that there may be a possible association between high AgNOR counts and malignant transformation $[20,21]$. It is interesting to hypothesize, therefore, that the numbers, the shape, and the distribution of AgNORs within the nucleus might be of potential use in predicting behavior in breast carcinomas. In this study, we investigated the usefulness of the AgNOR technique in assessing the ER, PR, P53, and HER2/neu tumor markers in breast carcinomas.

\section{Materials and Methods}

One hundred and fifty seven formalin-fixed, paraffinembedded tissue block samples from the breast lesions (including 124 cases of invasive ductal carcinoma, 13 in situ ductal carcinomas, and 20 cases of benign breast lesions) were investigated in this study.

All biopsies were obtained from females with breast lesions, their ages ranging from 16 to 80 years with mean age of 43 years old. Patients with breast cancer $(n=137)$ ascertained as cases, and those with benign breast lesions were ascertained as controls $(n=20)$.

2.1. Sample Processing. Serial sections on poly-L-lysinecoated slides for immunohistochemistry (IHC) and one section on a regular slide for hematoxylin and eosin stain were prepared from each case. The Immunohistochemical staining: immunohistochemistry staining was performed as described previously $[22,23]$. Slides were heated overnight at $56^{\circ} \mathrm{C}$, followed by deparaffinization through graded ethyl alcohols and rehydration. Before immunostaining with antibodies, the tissues were treated with $10 \mathrm{mM}$ sodium citrate buffer at $1001 \mathrm{C}$ for 15 minutes for antigenic retrieval. The samples were incubated with $0.3 \%$ hydrogen peroxide (Merck, Germany) in methanol for 30 minutes to inhibit endogenous peroxidase activity, washed 3 times with phosphate-buffered saline (PBS). After blocking nonspecific sites with horse normal serum (DAKO, Denmark) diluted in phosphate buffer (PBS), the slides were rinsed with distill water $2 \times 5$ minutes in PBS. Primary antibodies were incubated for 8 hours in a humidity chamber using the following dilutions: p53 (clone DO-7, titer 1:50, Dako, Denmark), HER-2/neu (titer 1:50, Dako, Denmark), ER (clone 1D5, Dako, Denmark), and PR (clone PgR 636, Dako, Denmark), was performed by applying the avidin-biotinPeroxidase complex method. After $2 \times 5$ minutes in rinse PBS, secondary antibody (LSAB2, DAKO) was incubated for 30 minutes in the same chamber. Detection of the primary antibody was obtained using the Strepto ABC, LSAB2 system (DAKO) according to the manufacture instructions. The slides were counter stained with hematoxylin, mounted and analyzed with light microscope. All slides were performed at the same time and submitted to standard methods. Known positive and negative cases were used as external controls. Two investigators (M. A. Al-Adhraei and H. G. Ahmed) evaluated the slides independently. Positive expression for each tumor marker was defined as in the literature: ER and PR were considered positive when $>10 \%$ of the nuclei were stained in 10 high power field (HPF) [24, 25]. The HER$2 /$ neu was considered negative when it had score 0 and +1 and positive with score +2 and +3 . To be considered as +2 and +3 , the cellular membrane should be completely stained in more than $10 \%$ of the tumor cells. Cells without staining or with weak staining in part of the cell membrane and in less than $10 \%$ of the tumor cells were considered negative [26]. P53 was considered positive when $>5 \%$ of the nuclei were stained in $10 \mathrm{HPF}$ [27].

2.2. AgNOR Staining Method. The sections were stained according to the AgNOR method. Working solution was freshly prepared by mixing one volume of $2 \%$ gelatin in $1 \%$ formic acid solution and two volumes of $50 \%$ aqueous silver nitrate solution. All sections were incubated with this silver solution for 30 minutes at room temperature in a dark medium, and they were protected in the dark until each slide was analyzed. Two investigators, blind to the study groups, analyzed the silver-stained cells under light microscope (Olympus BX-51, Japan) at 1000x magnification. All sections were screened horizontally from left to right, and AgNORs were counted in the nuclei of the first 50 nucleated cells. Cells with pyknotic nuclei were not counted. The AgNOR count was made adopting the method described by Ahmed and Babiker [28].

AgNORs, which were visible as black-dark brown dots located within the nuclei of the cells, were counted; overlapped black dots were counted as one structure.

2.3. Statistical Analysis. SPSS version 17 statistical software was used for statistical analysis. The numeric results (AgNOR counts and tumor markers) were expressed as mean $\pm \mathrm{SD}$, and the $95 \%$ confidence intervals (CIs) of the means were calculated. The $X^{2}$ test was used to compare the differences in categorical variables between the groups. Relationships between variables were analyzed using Pearson's correlation analysis. A $P<0.05$ was considered statistically significant. 


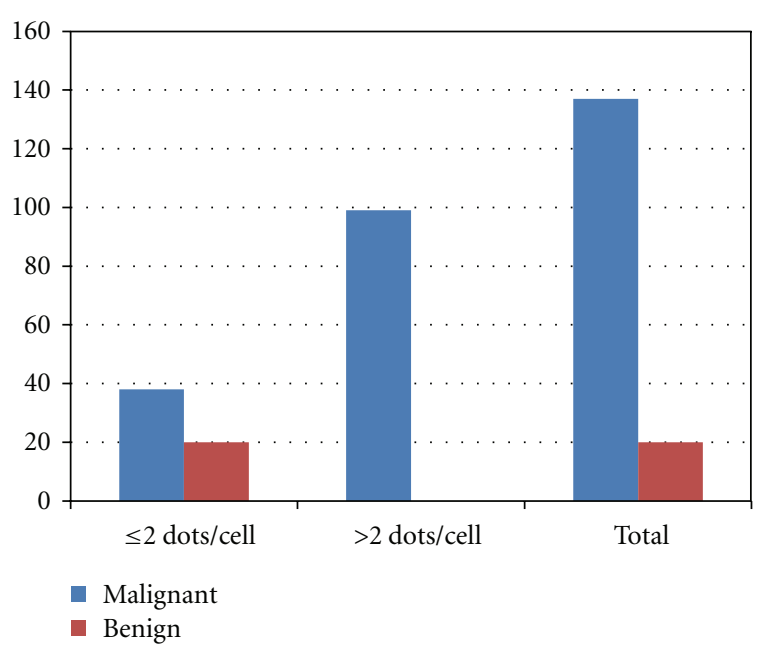

Figure 1: Description of mean AgNORs counts in benign and malignant groups.

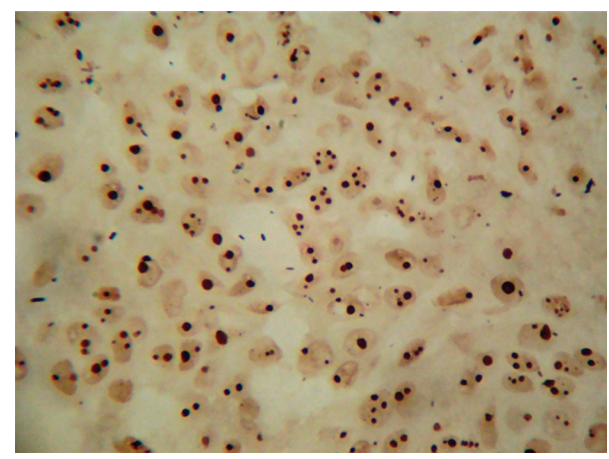

Figure 2: AgNORs dots in IDC.

\section{Results}

AgNORs were clearly visible on light microscopical examination as black silver binding dots within nuclei stained orange. AgNOR silver stain was applied in all benign and malignant tumors. As it is explored in Figure 1, there is a significant differences in the mean of AgNORs counting among malignant $($ mean $=2.57)$ and benign $($ mean $=1.26)$ $(P<0.0001)$ study subjects, (see Figures 2, 3, and 4). Details of mean AgNORs counting and association with other variables were summarized in Table 1. In malignant group, with age at diagnosis, AgNORs counts did not show significant differences $(P=0.183)$. AgNORs counts with other prognostic markers were evaluated, where counts of these nuclear loops were significantly different with ER, PR, and p53 expression but not with HER2. AgNORs counts were significantly inversely associated with $\mathrm{PR}$ expression $(P=$ $0.010)$ and in to some extent with ER expression $(P=0.053)$ $(\mathrm{ER}+\mathrm{ve}=2.45$ versus $\mathrm{ER}-\mathrm{ve}=2.71$ and $\mathrm{PR}+\mathrm{ve}=2.36$ versus $P R-v e=2.71)$. With p53, AgNORs mean counts showed positive significant association $(P=0.001)(\mathrm{p} 53+\mathrm{ve}$ $=2.81$ versus $\mathrm{p} 53-\mathrm{ve}=2.36$ ). Tumor grade was significantly different by AgNORs mean counting $(P=0.022)$ (grade I $=2.66$ versus grade III $=3.41 ; P=0.001)$ while histological

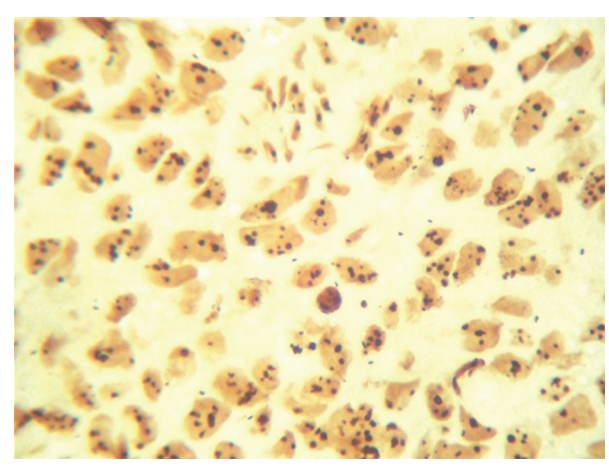

Figure 3: AgNORs dots in IDC.

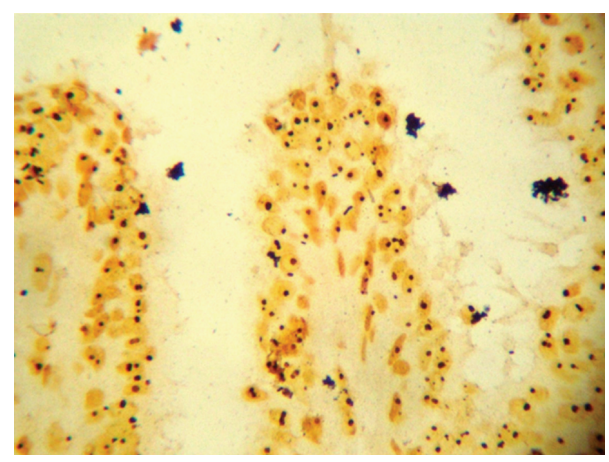

FIgURE 4: AgNORs dots in benign breast tumor.

type (invasive ductal carcinoma (IDC) and NonIDC) $(P=$ $0.351)$, tumor size $(P=0.747)$, and lymph node status $(P=$ 0.681 ) did not show any significant differences in AgNORs mean counting.

\section{Discussion}

The management of breast carcinoma depends on a number of morphological and biological factors. These include tumor type and grade the presence of local invasion and lymph node metastases, the degree and proportion of nuclei showing atypia (e.g., hyperchromatism, pleomorphism, and mitotic activity), and the presence or absence of particular tumor markers (e.g., ER and PR receptor status) [14].

The increased number of AgNOR dots is, in many cases, considered to be of diagnostic and prognostic significance in tumor pathology, because of its direct relationship to the frequency of cell proliferation and other requirements for ribosome biogenesis [29]. Although the number of AgNORs is increased in malignancy, some workers considered it as not diagnostic due to overlap with benign proliferation [30]. It seems that although the number of AgNORs per cell is not discriminatory enough on its own to determine malignancy, the addition of size or area measurements using image analysis gives improved diagnostic and prognostic specificity $[31,32]$.

In the present study, it can be seen that mean AgNOR count among the malignant cases is significantly higher than in the benign, which is a similar finding with the study 
TABle 1: Association between mean AgNOR counts and different variables.

\begin{tabular}{|c|c|c|c|c|c|}
\hline \multicolumn{2}{|c|}{ Variables } & \multicolumn{2}{|c|}{ AgNORs count } & \multirow{2}{*}{$\begin{array}{l}\text { Mean of } \\
\text { AgNORs }\end{array}$} & \multirow{2}{*}{$P$ value } \\
\hline & & $\leq 2$ dots/cell & $>2$ dots/cell & & \\
\hline \multirow{2}{*}{ Age } & $\leq 40$ & 15 & 36 & 2.49 & \multirow{2}{*}{0.73} \\
\hline & $>40$ & 23 & 63 & 2.67 & \\
\hline \multirow{2}{*}{ ER } & $+\mathrm{ve}$ & 26 & 47 & 2.45 & \multirow{2}{*}{0.05} \\
\hline & $-\mathrm{ve}$ & 12 & 52 & 2.71 & \\
\hline \multirow{2}{*}{$\mathrm{PR}$} & $+\mathrm{ve}$ & 22 & 32 & 2.36 & \multirow{2}{*}{0.010} \\
\hline & $-\mathrm{ve}$ & 16 & 67 & 2.71 & \\
\hline \multirow{2}{*}{ HER2 } & $+\mathrm{ve}$ & 8 & 27 & 2.58 & \multirow{2}{*}{0.997} \\
\hline & $-\mathrm{ve}$ & 30 & 72 & 2.57 & \\
\hline \multirow{2}{*}{ P53 } & $+\mathrm{ve}$ & 14 & 52 & 2.81 & \multirow{2}{*}{0.001} \\
\hline & -ve & 24 & 47 & 2.36 & \\
\hline \multirow{2}{*}{ Histological type } & IDC & 32 & 92 & 2.60 & \multirow{2}{*}{0.351} \\
\hline & NIDC & 6 & 7 & 2.38 & \\
\hline \multirow{3}{*}{ Tumor size } & $<2 \mathrm{~cm}$ & 1 & 6 & 2.80 & \multirow{3}{*}{0.747} \\
\hline & $2-5 \mathrm{~cm}$ & 20 & 54 & 2.50 & \\
\hline & $>5 \mathrm{~cm}$ & 6 & 19 & 2.66 & \\
\hline \multirow{3}{*}{ Tumor grade } & Grade I & 7 & 15 & 2.40 & \multirow{3}{*}{0.022} \\
\hline & Grade II & 16 & 32 & 2.37 & \\
\hline & Grade III & 0 & 17 & 3.41 & \\
\hline \multirow{2}{*}{$\begin{array}{l}\text { Lymph node } \\
\text { status }\end{array}$} & -ve LN & 4 & 16 & 2.44 & \multirow{2}{*}{0.681} \\
\hline & +ve LN & 18 & 43 & 2.52 & \\
\hline
\end{tabular}

of Guski et al. [33]. They determined the diagnostic and prognostic value of AgNORs in atypical ductal hyperplasia $(\mathrm{ADH})$, ductal carcinoma in situ (DCIS), and microinvasive ductal carcinoma (MDCA) of the breast. AgNOR number and total AgNOR area increased from ADH to DCIS. The highest values were recorded in cases of DCIS with microinvasion. Differences between ADH and intraductal or microinvasive ductal carcinoma were statistically significant. Within the group of intraductal carcinomas, the lowest values were measured in the solid type and highest values in the comedo type.

Although significant inverse correlation was reported between proliferation markers and histopathological grade in a serial of 36 breast carcinomas [34], we found a significant positive association between tumor grade and $\operatorname{AgNORs}(P=$ $0.001)$. However, similar findings were reported by several studies [33-35].

In the present study, significant inverse correlations were found between proliferation markers and ER and PR receptor status and such findings were previously reported $[33,34]$. The relation between ER receptors and AgNORs within breast cancer cells was analyzed in 49 invasive breast carcinomas by digital image analysis. A higher AgNOR content in ER-negative cells and a special clustering phenomenon in ER-positive tumor cells were found. Correlation with other criteria of malignant potential could be exclusively demonstrated for ER-negative cells. ER-negative cells of breast cancer can be characterized as the more malignant and possibly prognosis-dictating cell fraction. Thus, ER-negative cells probably contribute more to the progression of the tumor disease and furthermore to the prognosis than ERpositive cells [36].

The oncosuppressor proteins pRb and p53 may exert a key role in coupling growth and proliferation by controlling both ribosome biogenesis and cell cycle progression. In the present study, we found a significant positive relation between AgNOR and P53. The AgNOR response in human breast cancer has been found suggestive of being affected by the status of the oncosuppressor proteins p53 [37, 38]. In 71 human primary breast carcinomas with a mutated p53, as studied by Treré et al. [38], the mean AgNOR area was greater than in 272 tumors with a normal (wild-type) p53. Therefore, we think that the type of P53 may play a role in the mean AgNOR count.

Although HER2/neu did not show any correlation with AgNORs in the present study, the study by Bánkfalvi et al. [39] indicated conflicting findings, which might be attributed to our criteria for considering the positive results. They applied immunohistochemistry (IHC) using the A0485 and CB11 antibodies and fluorescence in situ hybridisation (FISH) for detection of HER2 in 74 routinely processed breast carcinoma specimens. The rapidity of cellular proliferation was assessed by standardised AgNOR analysis and compared with HER2 status. Protein overexpression was found in $30 / 74$ cases by A0485 and in 20/74 by CB11 antibodies, while amplification was detected in 22/74 carcinomas by FISH. Twenty-seven of 74 tumors were high-level AgNOR expressors (mean AgNOR area >3.369 microm2), 19 of which revealed amplification. They concluded that the AgNOR analysis may represent an additional tool to select 
patients as candidates for Herceptin therapy due to the strong negative predictor value.

\section{Conclusion}

We conclude that mean AgNOR counts correlate with markers of increased malignant potential in breast carcinomas. However, AgNORs seem to reflect proliferationindependent cellular and nucleolar activity of tumor cells, as well. We recommend the use of AgNOR analysis for prediction of positive or negative expression of ER, PR, and P53 in routine paraffin sections, particularly in low-income countries, where some of these markers may be unavailable in routine histopathology.

\section{References}

[1] WHO, "Breast cancer: prevention and control," Cancer, 2011, http://www.who.int/cancer/detection/breastcancer/en/index. html.

[2] M. P. Coleman, M. Quaresma, F. Berrino et al., "Cancer survival in five continents: a worldwide population-based study (CONCORD)," The Lancet Oncology, vol. 9, no. 8, pp. 730-756, 2008.

[3] G. Blanco, M. Alavaikko, A. Ojala et al., "Estrogen and progesterone receptors in breast cancer: relationships to tumour histopathology and survival of patients," Anticancer Research, vol. 4, no. 6, pp. 383-390, 1984.

[4] M. Barbareschi and C. Doglioni, "The immunohistochemical detection of steroid hormone receptors in breast cancer: open problems and new perspectives," Pathologica, vol. 94, no. 3, pp. 115-120, 2002.

[5] M. B. Kastan, O. Onyekwere, D. Sidransky, B. Vogelstein, and R. W. Craig, "Participation of p53 protein in the cellular response to DNA damage," Cancer Research, vol. 51, no. 23, part 1, pp. 6304-6311, 1991.

[6] D. M. Barnes and R. S. Camplejohn, "P53, apoptosis, and breast cancer," Journal of Mammary Gland Biology and Neoplasia, vol. 1, no. 2, pp. 163-175, 1996.

[7] R. Bookstein, D. MacGrogan, S. G. Hilsenbeck, F. Sharkey, and D. C. Allred, "p53 is mutated in a subset of advanced-stage prostate cancers," Cancer Research, vol. 53, no. 14, pp. 33693373, 1993.

[8] L. Temmim, H. Baker, and F. Sinowatz, "Immunohistochemical detection of p53 protein expression in breast cancer in young Kuwaiti women," Anticancer Research, vol. 21, no. 1, pp. 743-748, 2001.

[9] S. Metcalfe, T. K. Wheeler, S. Picken, S. Negus, and A. Jo Milner, "P53 autoantibodies in 1006 patients followed up for breast cancer," Breast Cancer Research, vol. 2, no. 6, pp. 438443,2000

[10] A. Elzagheid, T. Kuopio, S. Pyrhönen, and Y. Collan, "Lymph node status as a guide to selection of available prognostic markers in breast cancer: the clinical practice of the future?" Diagnostic Pathology, vol. 1, no. 1, article 41, 2006.

[11] S. M. Ali, K. Leitzel, V. M. Chinchilli et al., "Relationship of serum HER-2/neu and serum ca $15-3$ in patients with metastatic breast cancer," Clinical Chemistry, vol. 48, no. 8, pp. 1314-1320, 2002.
[12] P. M. Ravdin and G. C. Chamness, "The c-erbB-2 protooncogene as a prognostic and predictive marker in breast cancer: a paradigm for the development of other macromolecular markers," Gene, vol. 159, no. 1, pp. 19-27, 1995.

[13] R. Naidu, M. Yadav, S. Nair, and M. K. Kutty, "Expression of c-erbB3 protein in primary breast carcinomas," The British Journal of Cancer, vol. 78, no. 10, pp. 1385-1390, 1998.

[14] E. Sivridis and B. Sims, "Nucleolar organiser regions: new prognostic variable in breast carcinomas," Journal of Clinical Pathology, vol. 43, no. 5, pp. 390-392, 1990.

[15] R. Smith and J. Crocker, "Evaluation of nucleolar organizer region-associated proteins in breast malignancy," Histopathology, vol. 12, no. 2, pp. 113-125, 1988.

[16] M. J. Beresford, G. D. Wilson, and A. Makris, "Measuring proliferation in breast cancer: practicalities and applications," Breast Cancer Research, vol. 8, no. 6, article 216, 2006.

[17] W. A. Mourad, B. Erkman-Balis, S. Livingston et al., "Argyrophilic nucleolar organizer regions in breast carcinoma. Correlation with DNA flow cytometry, histopathology, and lymph node status," Cancer, vol. 69, no. 7, pp. 1739-1744, 1992.

[18] A. Dasgupta, R. N. Ghosh, R. Sarkar, R. N. Laha, T. K. Ghosh, and C. Mukherjee, "Argyrophilic nucleolar organiser regions (AgNORs) in breast lesions," Journal of the Indian Medical Association, vol. 95, no. 9, pp. 492-494, 1997.

[19] J. Rzymowska, "AgNOR counts and their combination with flow cytometric analyses and clinical parameters as a prognostic indicator in breast carcinoma," Tumori, vol. 83, no. 6, pp. 938-942, 1997.

[20] D. Ploton, M. Menager, P. Jeannesson, G. Himber, F. Pigeon, and J.-J. Adnet, "Improvement in the staining and in the visualization of the argyrophilic proteins of the nucleolar organizer region at the optical level," Histochemical Journal, vol. 18, no. 1, pp. 5-14, 1986.

[21] M. E. Fallowfield, A. R. Dodson, and M. G. Cook, "Nucleolar organizer regions in melanocytic dysplasia and melanoma," Histopathology, vol. 13, no. 1, pp. 95-99, 1988.

[22] J. L. Pedrini, M. Pedrini, R. F. Savaris, L. Machado, M. Grudzinski, and C. G. Zettler, "Reassessing tumor markers in local recurrences of breast cancer: a new insight," Medical Science Monitor, vol. 10, no. 12, pp. BR462-BR467, 2004.

[23] M. V. Croce, M. Isla-Larrain, F. Remes-Lenicov et al., "MUC1 cytoplasmic tail detection using CT33 polyclonal and CT2 monoclonal antibodies in breast and colorectal tissue," Histology and Histopathology, vol. 21, pp. 849-855, 2006.

[24] M. Ferrero-Poüs, M. Trassard, V. Le Doussal, K. Hacène, M. Tubiana-Hulin, and F. Spyratos, "Comparison of enzyme immunoassay and immunohistochemical measurements of estrogen and progesterone receptors in breast cancer patients," Applied Immunohistochemistry and Molecular Morphology, vol. 9, no. 3, pp. 267-275, 2001.

[25] A. E. Pinto, S. André, C. Laranjeira, and J. Soares, "Correlations of cell cycle regulators (p53, p21, pRb and mdm2) and c-erbB-2 with biological markers of proliferation and overall survival in breast cancer," Pathology, vol. 37, no. 1, pp. 45-50, 2005.

[26] T. W. Jacobs, A. M. Gown, H. Yaziji, M. J. Barnes, and S. J. Schnitt, "Specificity of HercepTest in determining HER-2/neu status of breast cancers using the United States Food and Drug Administration-approved scoring system," Journal of Clinical Oncology, vol. 17, no. 7, pp. 1983-1987, 1999. 
[27] C. Pfister, L. Moore, P. Allard et al., "Predictive value of cell cycle markers p53, MDM2, p21, and Ki-67 in superficial bladder tumor recurrence," Clinical Cancer Research, vol. 5, no. 12, pp. 4079-4084, 1999.

[28] H. G. Ahmed and A. A. Babiker, "Assessment of cytological atypia, AgNOR and nuclear area in epithelial cells of normal oral mucosa exposed to toombak and smoking," Rare Tumors, vol. 1, no. 18, pp. 28-30, 2009.

[29] S. M. Maria Luiza, C. Benedicto, J. Russo, W. Planding, and U. Schenck, "Image analysis of the AgNOR response in rastransformed human breast epithelial cells," Acta Histochemica, vol. 110, no. 3, pp. 210-216, 2008.

[30] E. Sivrides, P. Anastasiadis, and M. von Lüdinghausen, "Argyrophilic staining for nucleolar organizer region (AgNOR). A suitable methodology for differential diagnosis of breast lesions?" Zentralblatt fur Pathologie, vol. 138, no. 2, pp. 103 107, 1992.

[31] J. Ruschoff, K. Neumann, H. Contractor, K. Plate, and C. Thomas, "Assessment of nucleolar organizer regions by automatic image analysis in breast cancer: correltion with DNA content, proliferation rate, receptor status and histopathological grading," Journal of Cancer Research and Clinical Oncology, vol. 116, no. 5, pp. 480-485, 1990.

[32] J. A. Giménez-Mas, M. P. Gallego-Calvo, M. P. Sanz-Moncasi et al., "AgNOR evaluation by image processing methods. Staining modifications and results in 126 invasive ductal breast carcinomas," Analytical and Quantitative Cytology and Histology, vol. 18, no. 1, pp. 9-18, 1996.

[33] H. Guski, P. Hufnagl, O. Kaufmann, M. Krause, and K. J. Winzer, "AgNOR analysis of atypical ductal hyperplasia and intraductal carcinoma of the breast," Analytical and Quantitative Cytology and Histology, vol. 22, no. 3, pp. 206212, 2000.

[34] À. Bànkfalvi, D. Öfner, K. W. Schmid et al., "Standardized in situ AgNOR analysis in breast pathology: diagnostic and cell kinetic implications," Pathology Research and Practice, vol. 195, no. 4, pp. 219-229, 1999.

[35] D. Öfner, B. Bier, S. Heinrichs et al., "Demonstration of silver-stained nucleolar organizer region associated proteins (AgNORs) after wet autoclave pretreatment in breast carcinoma: correlation to tumor stage and long-term survival," Breast Cancer Research and Treatment, vol. 39, no. 2, pp. 165176, 1996.

[36] L. Günther, P. Hufnagl, K. J. Winzer, and H. Guski, "Different proliferation patterns in breast cancer: AgNOR measurements in ER-negative and ER-positive tumor cells," Analytical Cellular Pathology, vol. 20, no. 4, pp. 155-162, 2000.

[37] M. Derenzini, C. Ceccarelli, D. Santini, M. Taffurelli, and D. Treré, "The prognostic value of the AgNOR parameter in human breast cancer depends on the pRb and p53 status," Journal of Clinical Pathology, vol. 57, no. 7, pp. 755-761, 2004.

[38] D. Treré, C. Ceccarelli, L. Montanaro, E. Tosti, and M. Derenzini, "Nucleolar size and activity are related to pRb and p53 status in human breast cancer," Journal of Histochemistry and Cytochemistry, vol. 52, no. 12, pp. 1601-1607, 2004.

[39] A. Bánkfalvi, G. Giuffrè, D. Ofner et al., "Relationship between HER2 status and proliferation rate in breast cancer assessed by immunohistochemistry, fluorescence in situ hybridisation and standardised AgNOR analysis," International Journal of Oncology, vol. 23, no. 5, pp. 1285-1292, 2003. 


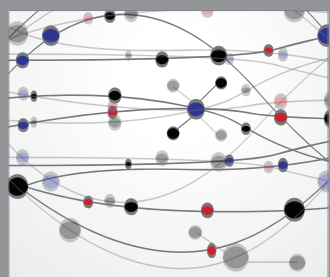

The Scientific World Journal
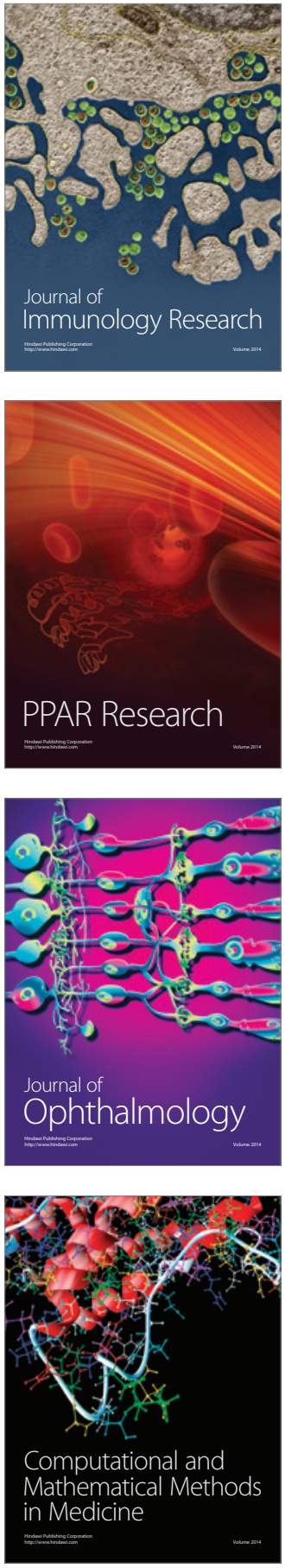

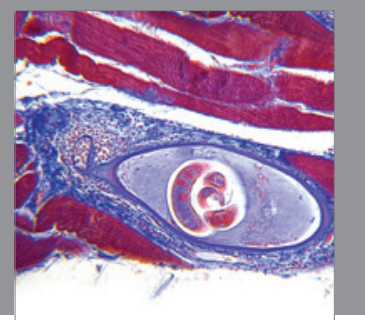

Gastroenterology

Research and Practice
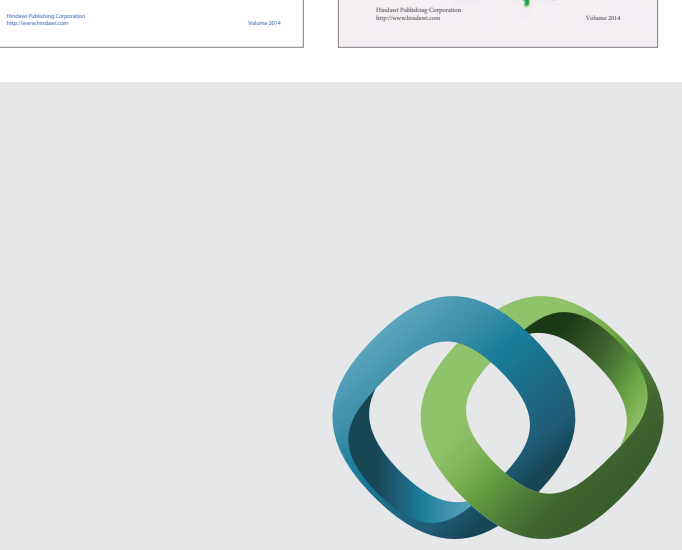

\section{Hindawi}

Submit your manuscripts at

http://www.hindawi.com
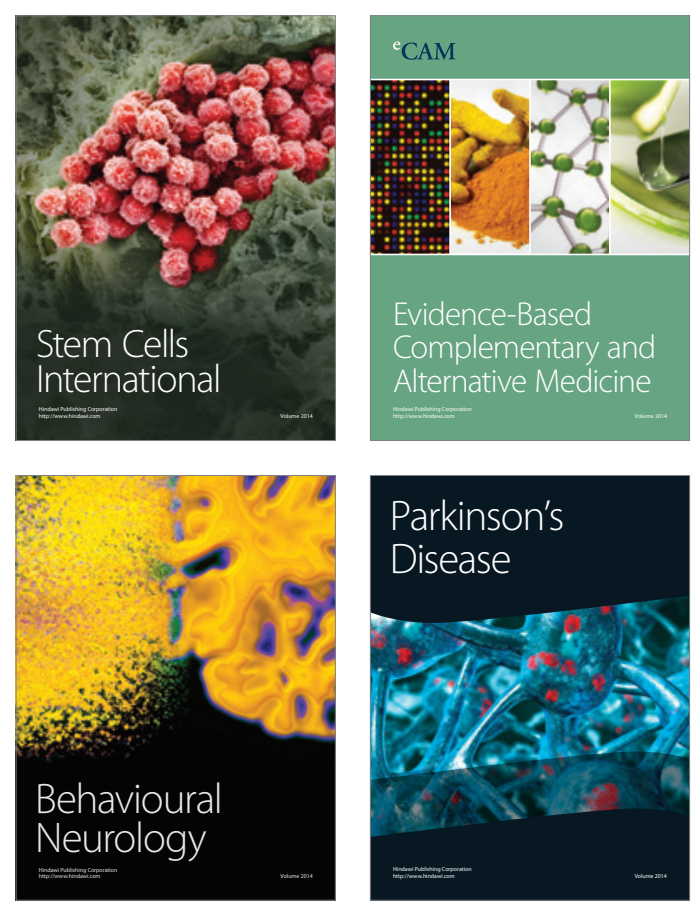

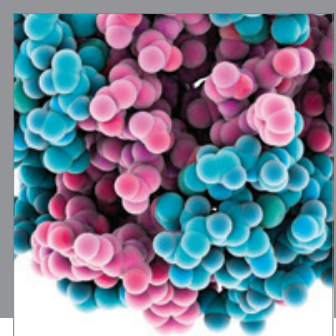

Journal of
Diabetes Research

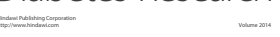

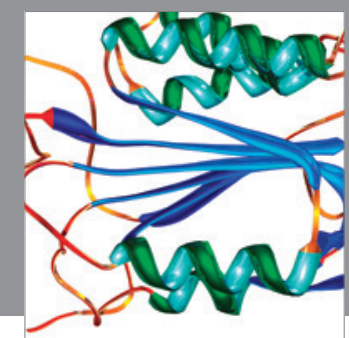

Disease Markers
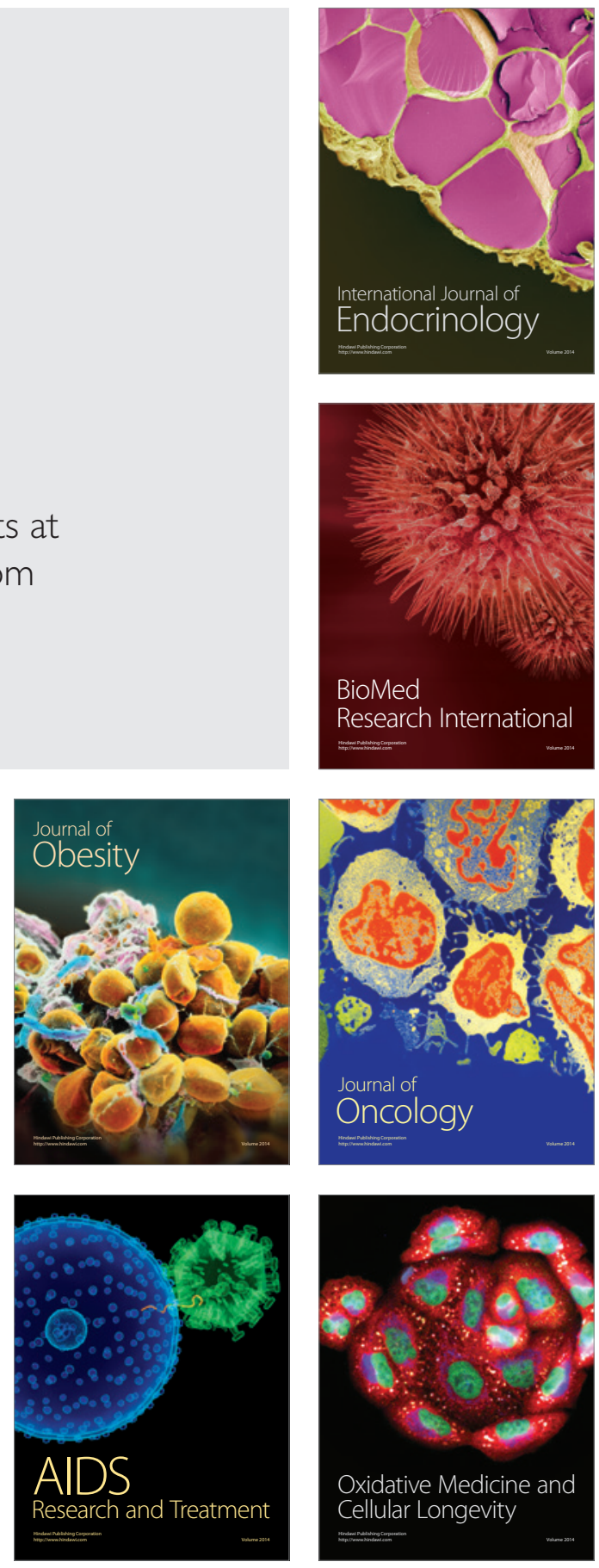